\title{
ANALIZA ZAPEWNIENIA BEZPIECZEŃSTWA PRACY W ZAKLADZIE PRODUKUJĄCYM KRUSZYWO
}

\begin{abstract}
Streszczenie: Wraz z rosnącą świadomością pracowników w zakresie bhp zmienia się podejście do sfery bezpiecznej pracy. Ze względu na liczne zagrożenia występujące $\mathrm{w}$ górnictwie dokonano analiz, których celem było zaproponowanie możliwości zapewnienia bezpiecznego miejsca pracy. Analizę przeprowadzono w zakładzie górniczym produkującym kruszywo ZEK Czarna Sędziszowska, który jest jednym z zakładów należących do przedsiębiorstwa Kruszgeo. Analizie poddano dane statystyczne pobrane z Wyższego Urzędu Górniczego dotyczące wypadkowości w górnictwie odkrywkowym w latach 2010 - 2017. Kolejno dokonano analizy wyników ankietowych, które zostały przeprowadzone wśród wszystkich pracowników omawianego zakładu Ankiety dotyczyły bezpieczeństwa w pracy oraz odczuwanych przez pracowników dolegliwości. Wybrane wyniki ankietowe porównano z wynikami z oceny ryzyka zawodowego przeprowadzonego według normy PN-N-18002. Przeprowadzona analiza i zaproponowane możliwości zwiększenia bezpieczeństwa pracy mogą zapewnić bezpieczne miejsce pracy w ZEK Czarna Sędziszowska i w innych zakładach odkrywkowych.
\end{abstract}

Slowa kluczowe: bezpieczeństwo, bhp, kruszywo

\section{Wstęp}

Eksploatowanie surowców naturalnych warunkuje powstawanie różnego rodzaju zagrożeń $\mathrm{w}$ obszarach zakładów górniczych, które oddziałują na życie i zdrowie pracowników. Każdy typ kopalni górniczej niesie ze sobą różnorakie zagrożenia, dlatego należy dokonywać odpowiednich analiz i identyfikacji zagrożeń, a kolejno inicjować właściwe działania zapobiegawcze. Niebezpieczeństwo pracy w kopalniach górniczych może wynikać przykładowo z zagrożeń pożarowych, zawałowych, wodnych i innych. Jednak, wypadkowość ta w dużej mierze zależy od czynnika ludzkiego, dlatego ważne jest, aby w sposób właściwy zarządzać bezpieczeństwem i higieną pracy. Aby to było możliwe, niezbędne jest prowadzenie wszelkich działań, dzięki którym zostanie zwiększona świadomość pracowników co do konieczności przestrzegania zasad bhp, jak i możliwe będzie zapobieganie prawdopodobnym zagrożeniom. W tym celu należy prowadzać okresowe szkolenia z zakresu bezpieczeństwa i higieny pracy, a także regularnie sprawdzać poziom bezpieczeństwa w pracy wśród wszystkich pracowników. Czynności te powinny być skoncentrowane na znalezieniu możliwych zagrożeń, ich przyczyn oraz skutków,

\footnotetext{
${ }^{1}$ inż., dominikasiwiec@o2.pl

${ }^{2}$ dr hab. inż., prof. PRz, Politechnika Rzeszowska, app@prz.edu.pl
} 
a także powinny zasygnalizować obszary, w których konieczne jest zwiększenie bezpieczeństwa pracy.

\section{Kreowanie bezpieczeństwa w pracy}

Bezpieczeństwo jest uznawane za stan pewności, spokoju oraz braku zagrożeń. Jest to także zdolność do ustrzeżenia się od szkód spowodowanych ryzykiem, niebezpieczeństwem bądź też zagrożeniami [1,2]. Jak wskazuje piramida Maslowa, potrzeba poczucia bezpieczeństwa jest jedną z podstawowych potrzeb człowieka. Jeżeli potrzeba ta nie zostaje spełniona, to człowiek nie może realizować innych działań, które mają na celu zaspokoić potrzebny należące do potrzeb wyższego rzędu. $\mathrm{Z}$ kolei bezpieczeństwo pracy jest działalnością, która nakierowana jest do zabezpieczenia pracownika przed możliwym wypadkiem bądź zagrożeniem w pracy. Bezpieczeństwo to jest realizowane dzięki stosowaniu odpowiednich środków technicznych, odpowiedniemu zorganizowaniu pracy, a także poprzez kształtowanie bezpiecznych zachowań ludzkich, które wyczulają pracownika na możliwe zagrożenia wypadkowe [3]. Zakłady pracy powinny we właściwy sposób organizować miejsce pracy, tak by pracownicy, na każdym stanowisku pracy czuli się bezpiecznie i komfortowo.

Nurt związany z organizacją bezpiecznego miejsca pracy pojawił się w Polsce w okresie lat osiemdziesiątych XX wieku. Działania mające zapewnić bezpieczeństwo w pracy określono jako zarządzanie bezpieczeństwem, jak i pojęcie bezpieczeństwa i higieny pracy. Zarządzanie bezpieczeństwem i higieną pracy uznawane jest za część ogólnego systemu zarzadzania organizacją, który nastawiony jest realizowanie polityki bezpieczeństwa oraz higieny pracy [4]. Wyróżniono trzy elementy, dzięki którym zarządzanie bezpieczeństwem i higieną pracy powinno być traktowane jako główne cele każdej z organizacji. Po pierwsze, ludzie nie mogą akceptować żadnego rodzaju wypadków, w szczególności ciężkich i śmiertelnych. Po drugie, społeczeństwo powinno zawsze podejmować działania, które zapewnią bezpieczeństwo podczas pracy i umożliwią uniknięcia strat w środowisku naturalnym. W momencie nie zachowywania tego typu działań, właściwe inspekcje powinny zawsze podejmować kroki w celu zwiększenia bezpieczeństwa technicznego oraz ekologicznego. Po trzecie, organizacje powinny być świadome tego, że dzięki zapewnieniu bezpiecznego miejsca pracy, należy zintegrować wszelkie działania zapewniające efektywną produkcję z działaniami bhp [5]. Jednakże, aby działania te mogły być odpowiednio realizowane, przedsiębiorstwa powinny stosować podejście systemowe, w którym czynności zarządzania bezpieczeństwem koncentrowane są tylko na sprawach najbardziej istotnych [6]. Przykładowo, jednym z systemów zarządzania bhp jest norma PN-N-18002, która zawiera wytyczne odnoszące się do 
$\overline{\text { identyfikacji zagrożeń, a także do oceny ryzyka zawodowego }[7,8] \text {. Początkowo, }}$ działania $\mathrm{w}$ obszarze bezpieczeństwa $\mathrm{w}$ pracy były skupione tylko na poprawie wyposażenia stanowisk, maszyn lub urządzeń. Wówczas w organizacjach panował niski poziom bezpieczeństwa. Jednak od momentu rozwinięcia ergonomii i większym skupieniu się na potrzebach ludzkich, a kolejno powstaniu w strategii proaktywnej poziom bezpieczeństwa pracy znacznie się poprawił. Od tego czasu, czyli od początku lat dziewięćdziesiątych XX wieku, zarządzanie bezpieczeństwem związane było także $\mathrm{z}$ planowaniem $\mathrm{i}$ zapobieganiem u źródła powstawaniu zagrożeń i niebezpieczeństw [5].

\section{Wypadkowość w górnictwie odkrywkowym od 2010 - 2017 roku}

Badania dotyczące bezpieczeństwa pracy zostały przeprowadzone w zakładzie odkrywkowym, czyli kopalni, w której wszelkie prace odbywają się powierzchni. W celu dokonania analizy liczby wypadków w tego typu zakładach wykorzystano dane statystyczne z Wyższego Urzędu Górniczego (rys. 1).

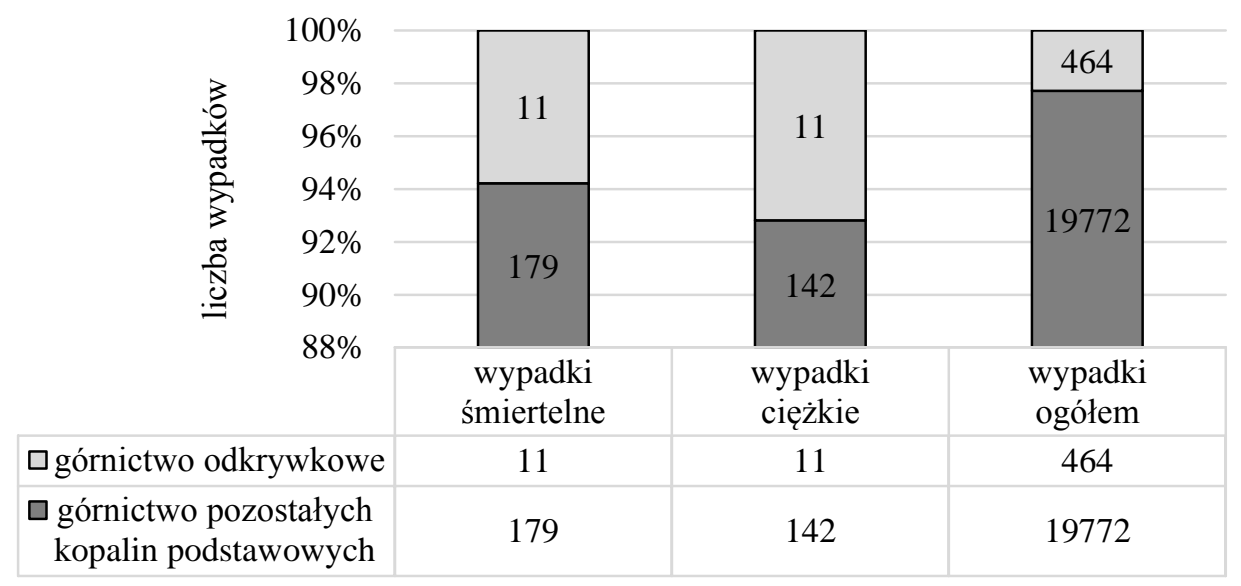

Rys. 1. Liczba wypadków w górnictwie odkrywkowym do liczby wszystkich wypadków w kopalniach podstawowych w latach $2010-2017$

Źródto: Opracowanie wtasne na podstawie [9]

W latach 2010 - 2017 zaobserwowano, że liczba wypadków w kopalniach odkrywkowych była stosunkowo niewielka do liczby wypadków w pozostałych kopalniach górniczych. Oprócz tego, liczba wypadków w zakładach odkrywkowych od 2010 do 2017 roku znacznie zmalała (rys. 2). 


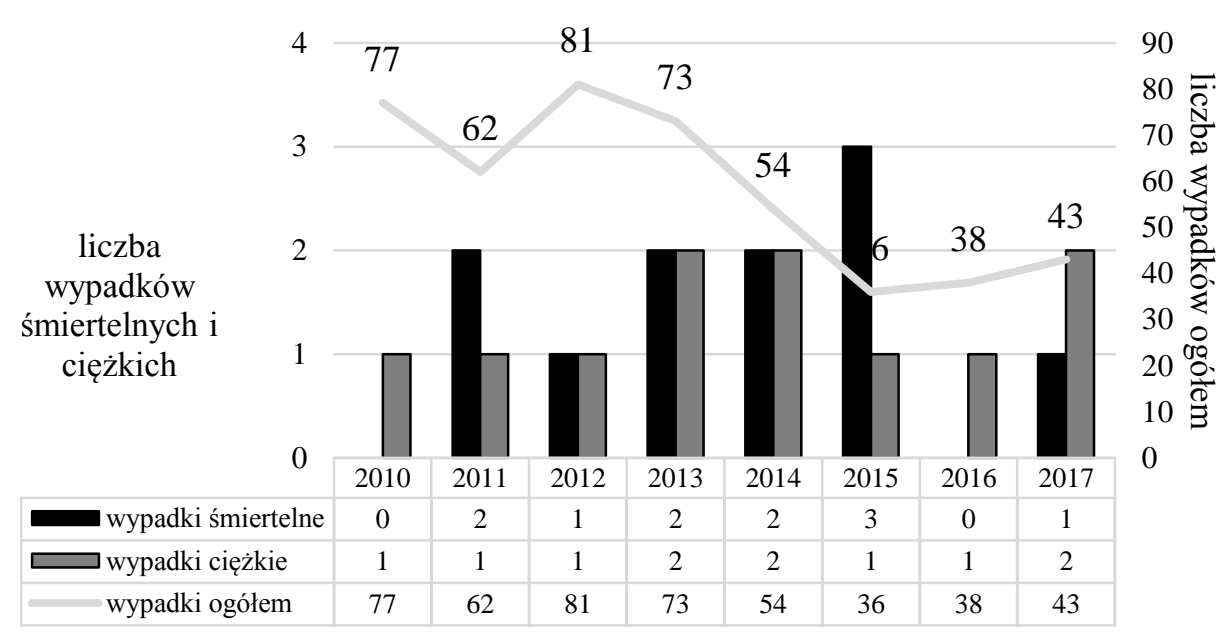

Rys. 2. Liczba wypadków osób z załogi własnej zakładów górniczych odkrywkowych w latach $2010-2017$

Źródto: Opracowanie własne na podstawie [9]

Wypadki ciężkie i śmiertelne w ciągu roku wynosiły w sumie 4\% wszystkich zdarzeń wypadkowych. Do wypadków ciężkich lub śmiertelnych w ciągu roku dochodziło maksymalnie dwa razy, wyjątkiem był rok 2015, w którym odnotowano trzy wypadki śmiertelne.

Przyczynami tych zdarzeń wypadkowych było na przykład naruszenie zasad bezpiecznego wykonywania pracy, samowolna próba udrożnienia zablokowanego zasypu wykorzystując płaskownik, poruszanie się pracownika $\mathrm{w}$ obszarze trasy przejazdów samochodów technologicznych, próba podjęcia usługi bez wymaganych uprawnień, czy błędna realizacja prac remontowych jak i ich zła organizacja [9].

\section{Charakterystyka ZEK Czarna Sędziszowska i realizowanej pracy}

Ze względu na planowaną realizację badań dotyczących bezpieczeństwa pracy w zakładach odkrywkowych, przeprowadzono badania pilotażowe w jednym z zakładów należących do przedsiębiorstwa Kruszgeo S.A.. Przedsiębiorstwo to powstało w 1957 roku w Rzeszowie. Działalność firmy prowadzona jest w 26 zakładach produkcyjnych i 5 zakładach usługowych. Zakłady te mają swą lokalizację na terenie województwa podkarpackiego oraz małopolskiego. Jednym z zakładów Kruszgeo, jest zakład górniczy ZEK (Zakład Eksploatacji Kruszywa) Czarna Sędziszowska, który znajduje się w województwie podkarpackim, niedaleko miasta Rzeszów [10]. Głównymi miejscami pracy, które wydzielono w tym zakładzie są m. in.: wyrobiska przygotowawcze, czynne wyrobiska górnicze, eksploatacyjne czy 
$\overline{\text { poeksploatacyjne, a także technologiczne. W części zakładu będącego zakładem }}$ górniczym, zostały wydzielone stanowiska pracy operatorów: spycharek, koparek pływających, urządzeń zgarniających i ładowarki, a także operatorów przenośników pływających i górniczych. W przypadku części zakładu, który nie jest zakładem górniczym wyróżniono pracę operatorów: urządzeń krusząco - sortujących, przenośników transportu międzyoperacyjnego, urządzeń sortująco - płuczących $\mathrm{i}$ innych [11].

W ZEK Czarna Sędziszowska wyróżnia się następujące stanowiska robocze:

- operator koparki,

- operator ładowarki,

- operator mistrz,

- operator urządzeń krusząco - sortujących,

- operator zespołu przenośników,

- elektromonter,

- kierownik,

- mechanik,

- spawacz,

- kasjer - sprzedawca [11].

Praca operatorów koparek, dobywa się na koparce gąsienicowej typu CAT oraz na koparce pływająco - chwytakowej. Operator koparki gąsienicowej wykopuje oraz ładuje surowce sypkie, takie jak żwiry i piaski na dany środek transportowy. Do jego obowiązków, zalicza się także zagarnianie i przemieszczanie na określoną zwałkę materiałów sypkich czy wierzchniej warstwy ziemi. W przypadku zadań realizowanych przez operatora koparki pływająco - chwytakowej, zalicza się do nich prace wydobywcze (wydobycie surowców tj. żwiry, piaski oraz gliny), które wykonuje na akwenach wodnych do 30 metrów od lustra wody. Do zadań operatorów ładowarek zalicza się ładowanie materiałów na środki transportowe, zgarnianie i transportowanie zwałki materiałów lub warstwy wierzchniej ziemi, a także wyrównywanie terenu i formowanie nasypów. Operator pogłębiarek, realizuje swą pracę na akwenie wodnym, jego prace polegają na wydobywaniu surowców i nadzorowaniu pracy pogłębiarki. Natomiast operator urządzeń krusząco sortujących wykonuje prace związane $\mathrm{z}$ konserwacją, remontem i modernizacją urządzeń i maszyn znajdujących się na terenie całego zakładu górniczego ZEK Czarna Sędziszowska. Także nadzoruje wszelkie prace, które odbywają się w zakładzie przeróbczym, dbając tym samym o stan techniczny urządzeń i elementów bezpieczeństwa. Pracami, które należą do operatora zespołu przenośników są przykładowo - obsługa tras przenośników taśmowych, znajdujących się w kopalniach odkrywkowych, czy dbałość o porządek wokół nich i stan bezpieczeństwa linek i wyłączników bezpieczeństwa [11]. 


\section{Analiza bezpieczeństwa pracy w ZEK Czarna Sędziszowska}

Badania pilotażowe przeprowadzono w kwietniu 2018 roku, w sposób ankietowy wśród wszystkich pracowników omawianego zakładu (14 osób).

Pierwsza $\mathrm{z}$ ankiet składała się $\mathrm{z} 16$ twierdzeń i obejmowała zasady bezpieczeństwa i higieny pracy. Przykład ankiety i zebrane wyniki z odpowiedzi przedstawiono za pomocą zbiorczego zestawienia (tab. 1).

Tab. 1. Przyktad ankiety i uzyskane wyniki ankietowanych

\begin{tabular}{|c|c|c|c|c|c|c|c|}
\hline \multirow{3}{*}{$\begin{array}{l}\text { Nazwa organizacji: ...................... } \\
\text { Lokalizacja: ............................... } \\
\text { Stanowisko: ........................... } \\
\text { Twierdzenie dotyczace ankietowanej } \\
\text { organizacji: }\end{array}$} & \multicolumn{7}{|c|}{ Skala odpowiedzi } \\
\hline & \multicolumn{4}{|c|}{$\begin{array}{l}\text { Nie zgadzam się } \quad \leftarrow \rightarrow \\
\text { Zdecydowanie nie }\end{array}$} & \multicolumn{3}{|c|}{$\begin{array}{r}\text { Zgadzam się } \\
\text { ecydowanie tak }\end{array}$} \\
\hline & 1 & 2 & 3 & 4 & 5 & 6 & 7 \\
\hline $\begin{array}{l}\text { W naszej organizacji przeprowadzane są } \\
\text { okresowe szkolenia z zakresu bhp. }\end{array}$ & - & - & - & - & 1 & - & 13 \\
\hline Szkolenia bhp są na wysokim poziomie. & - & - & - & - & - & 6 & 8 \\
\hline $\begin{array}{l}\text { Uczestniczyłem/-am w ostatnim roku } \\
\text { w szkoleniach z zakresu bhp. }\end{array}$ & - & - & - & - & - & - & 14 \\
\hline $\begin{array}{l}\text { Szkolenia z bhp w naszej organizacji } \\
\text { wnoszą wiele korzyści do sposobu } \\
\text { wykonywanej pracy. }\end{array}$ & - & - & - & 1 & - & 5 & 8 \\
\hline $\begin{array}{l}\text { Kierownictwo zawsze przestrzega zasad } \\
\text { bhp. }\end{array}$ & - & - & - & - & 1 & 2 & 11 \\
\hline $\begin{array}{l}\text { Kierownictwo zawsze wymaga od } \\
\text { pracowników przestrzegania zasad bhp. }\end{array}$ & - & - & - & - & - & 2 & 12 \\
\hline $\begin{array}{l}\text { Pracownicy informują przełożonych } \\
\text { o możliwych zagrożeniach na swoim } \\
\text { stanowisku pracy. }\end{array}$ & - & 4 & - & 2 & 1 & 4 & 3 \\
\hline $\begin{array}{l}\text { Pracownicy informują przełożonych } \\
\text { o możliwych zagrożeniach na } \\
\text { stanowiskach pracy innych niż swoje. }\end{array}$ & - & - & 3 & - & 7 & 2 & 2 \\
\hline $\begin{array}{l}\text { Nieprzestrzeganie zasad bhp } \\
\text { w naszej organizacji jest karalne. }\end{array}$ & 3 & 1 & 1 & 1 & 3 & 2 & 3 \\
\hline $\begin{array}{l}\text { Przestrzeganie zasad bhp } \\
\text { w naszej organizacji jest nagradzane. }\end{array}$ & 9 & - & 3 & 2 & - & - & - \\
\hline $\begin{array}{l}\text { Na moim stanowisku pracy występuje } \\
\text { duże zagrożenie życia i zdrowia. }\end{array}$ & - & 5 & 1 & 4 & - & - & 4 \\
\hline $\begin{array}{l}\text { Często zdarzało się, że podczas pracy moje } \\
\text { życie lub zdrowie było zagrożone. }\end{array}$ & - & 4 & 3 & 3 & 2 & 2 & - \\
\hline $\begin{array}{l}\text { Często zdarzało się, że podczas pracy } \\
\text { życie lub zdrowie innego pracownika było } \\
\text { zagrożone. }\end{array}$ & - & 4 & 1 & 5 & 1 & 3 & - \\
\hline Miałem/-am wypadek podczas pracy. & 7 & 2 & 2 & - & - & - & 3 \\
\hline
\end{tabular}




\begin{tabular}{l|c|c|c|c|c||c|c|}
\multicolumn{4}{c|}{ QUALITY PRODUCTION IMPROVEMENT } & \multicolumn{2}{c}{$\begin{array}{c}\text { 2018 } \\
\text { Nr 1(8) }\end{array}$} \\
\hline \hline $\begin{array}{l}\text { Byłem ś-30 } \\
\text { pracy. }\end{array}$ & 8 & 2 & 1 & - & - & - & 3 \\
\hline $\begin{array}{l}\text { Widziałem/-am sytuacje, gdy inny } \\
\text { pracownik nie przestrzegał zasad bhp. }\end{array}$ & 4 & 1 & 1 & 2 & - & - & 6 \\
\hline
\end{tabular}

Źródto: Opracowanie własne

W ankiecie umieszczono twierdzenia odnoszące się do szkoleń z bezpieczeństwa i higieny pracy w ZEK Czarna Sędziszowska (rys. 3).

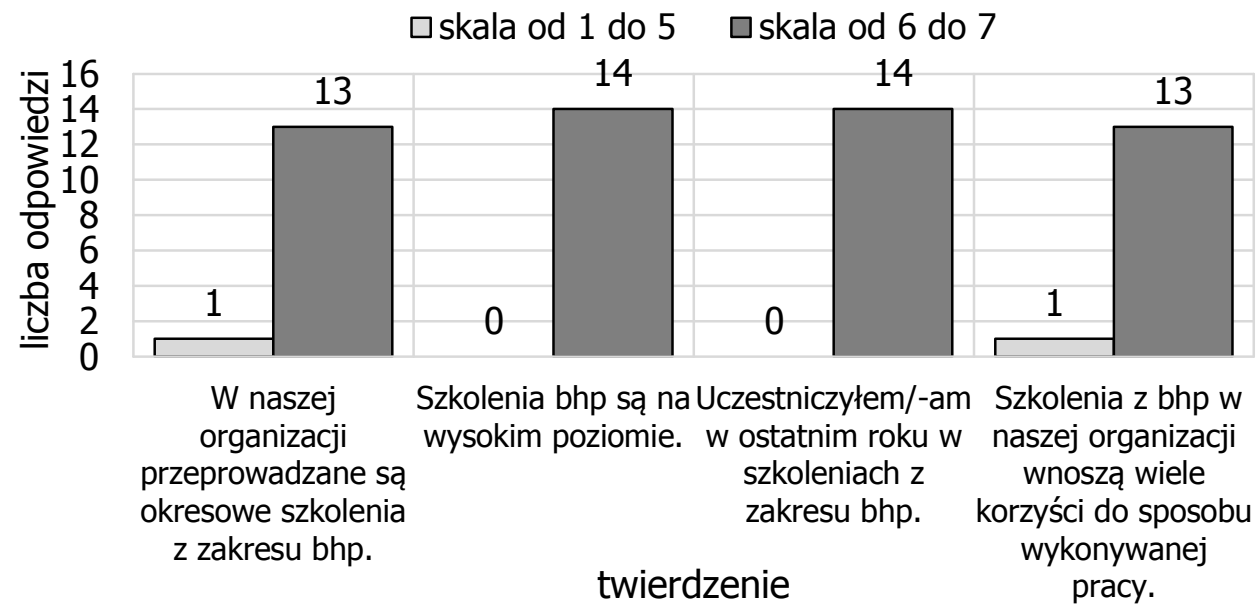

\section{Rys. 3. Odpowiedzi pracowników odnośnie szkoleń bhp}

Źródto: Opracowanie wlasne

Pracownicy przyznali, że są przeprowadzane tego typu szkolenia, oraz że są one na wysokim poziomie. Każdy z pracowników uczestniczył w ostatnim roku w takim szkoleniu oraz przyznał, że szkolenia te wnoszą wiele korzyści do sposobu wykonywanej przez nich pracy.

W związku z dużymi różnicami w skali i liczbie odpowiedzi dla twierdzeń odnoszących się do informowania przełożonych o zagrożeniach na stanowiskach pracy, zsumowano liczbę odpowiedzi w skali od 1 do 4 (gdzie „zdecydowanie nie”) oraz w skali od 5 do 7 (gdzie ,zdecydowanie tak”) (rys. 4). 


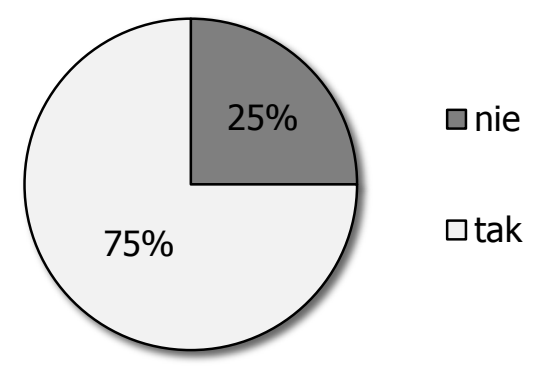

Rys.4. Odpowiedzi pracowników odnośnie informowania przełożonych o możliwych zagrożeniach na stanowiskach pracy

Źródto: Opracowanie własne

Jak wynika z badań ankietowych $25 \%$ pracowników nie informowała swoich przełożonych o możliwych zagrożeniach na ich stanowisku pracy, bądź na stanowisku pracy innego u pracownika.

Pomimo, że ankietowani przyznali, że kierownictwo przestrzega zasad bhp oraz wymaga tego samego od swoich pracowników, to w zakładzie często dochodziło do sytuacji niebezpiecznych (rys. 5).

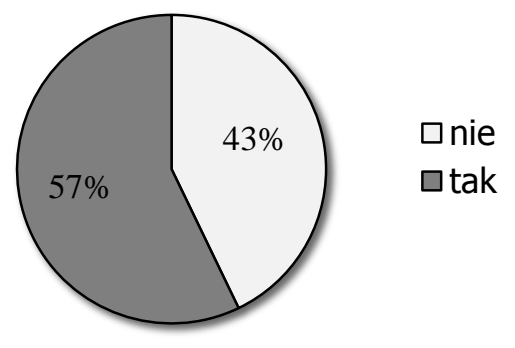

Rys. 5. Zagrożenie życia lub zdrowia pracowników

Źródto: Opracowanie własne

Tak jak poprzednio, ze względu na rozbieżność uzyskanych wyników, zsumowano liczbę odpowiedzi w skali od 1 do 4 (gdzie „zdecydowanie nie”) oraz w skali od 5 do 7 (gdzie ,zdecydowanie tak”). Większa połowa pracowników (57\%) uznała, że na ich stanowisku pracy występuje duże zagrożenie życia i zdrowia. Tyle samo osób stwierdziło, że często ich życie lub zdrowie było zagrożone oraz że widziało sytuację, gdy inny pracownik nie przestrzegał zasad bhp. $21 \%$ pracowników miało lub było świadkiem wypadku podczas pracy. 
W Zakładzie Eksploatacji Kruszywa Czarna Sędziszowska w 2017 roku została przeprowadzona ocena ryzyka zawodowego (rys. 6).

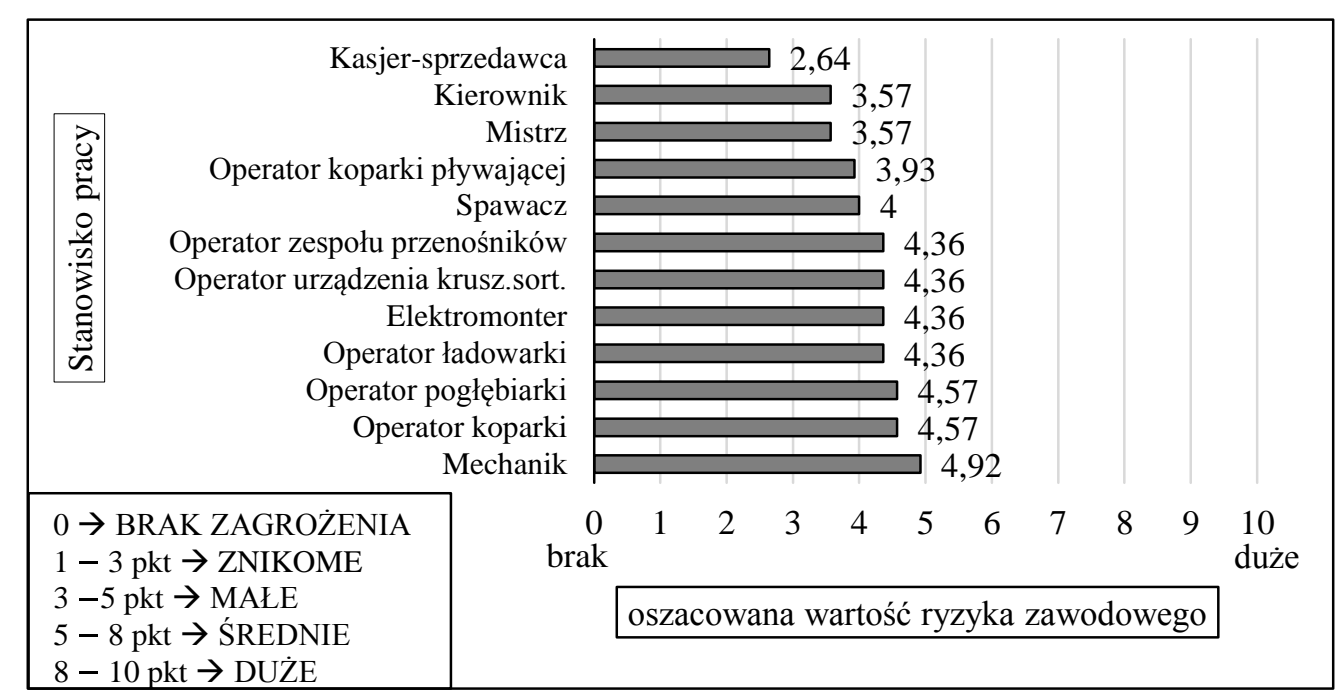

Rys. 6. Wyniki zoceny ryzyka zawodowego wg normy $\mathrm{PN}-\mathrm{N}-18002$

Źródto: Opracowanie wtasne na podstawie [11]

Ocenę ryzyka zawodowego przeprowadzono według normy PN-N-18002. Wyniki z niej uzyskane wskazują, że na każdym stanowisku pracy występuje małe zagrożenie życia i zdrowia (3 - 5 punktów).

Również w sposób ankietowy zapytano pracowników, które z dolegliwości są przez nich odczuwane (rys. 7). 


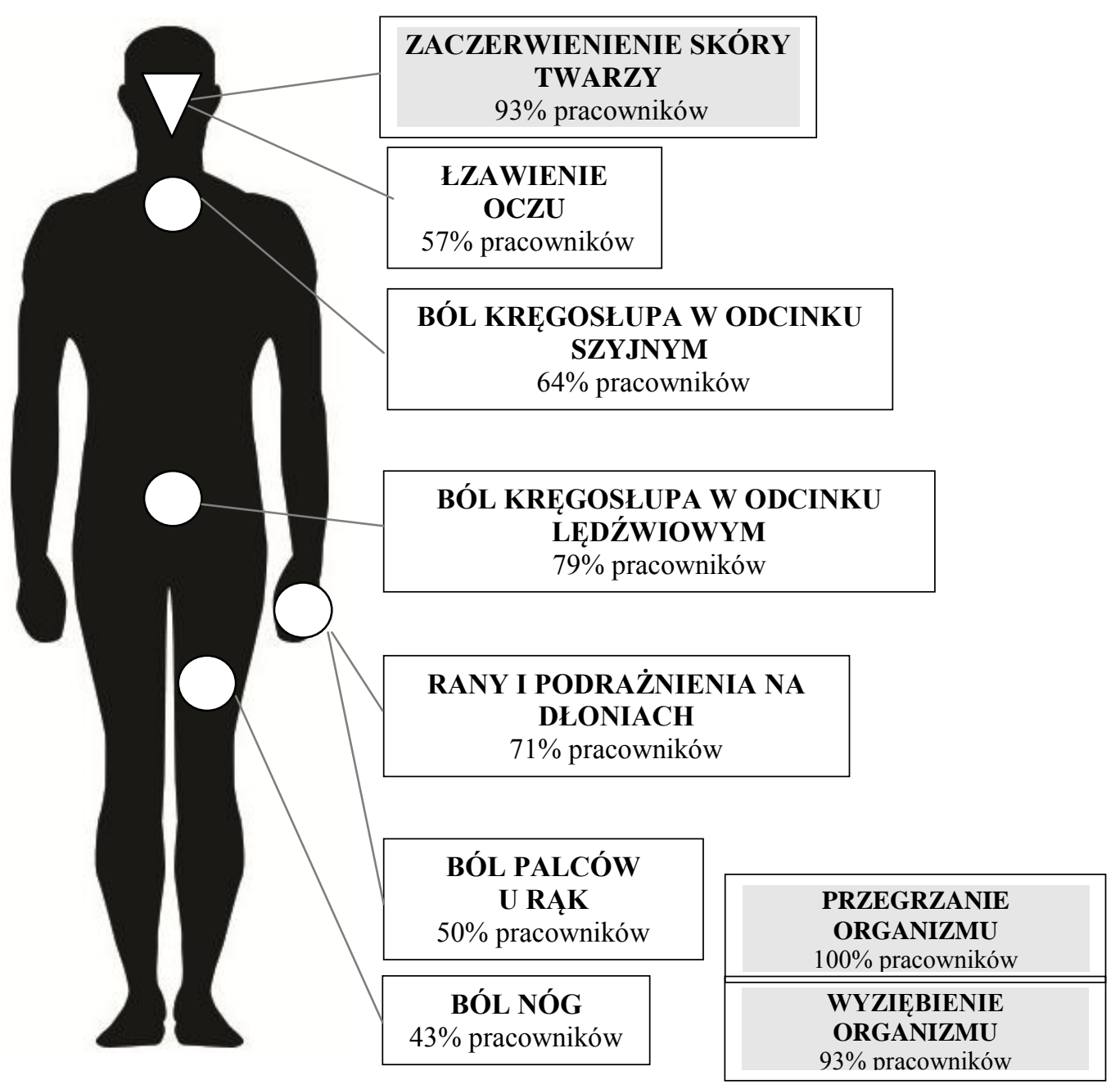

Rys. 7. Odczuwane przez pracowników dolegliwości

Źródto: Opracowanie własne

Wszyscy lub praktycznie wszyscy pracownicy wskazali, że zdecydowanie zgadzają się z odczuwaniem przez nich zaczerwienienia skóry twarzy (93\%), przegrzania (100\%) lub wyziębienia organizmu (93\%). Również 79\% pracowników odczuwa ból kręgosłupa w odcinku lędźwiowym, a 71\% rany i podrażnienia na dłoniach. Dużo osób skarży się na ból kręgosłupa w odcinku szyjnym, a także na łzawienie oczu. Pracownicy w 50\% przyznali, że odczuwają ból palców u rąk, a niewiele mniej osób (43\%) ból nóg. 


\section{Wnioski}

Przeprowadzona analiza wykazała, że należy podjąć działania dzięki którym możliwe będzie zwiększenie bezpieczeństwa pracy w omawianym zakładzie. W kopalni często dochodziło do sytuacji zagrażających życiu lub zdrowiu pracowników, co mogło być spowodowane wcześniej wspomnianymi dolegliwościami lub lekceważeniem przez pracowników zasad bhp. Zaproponowanymi działaniami, dzięki którym możliwe będzie zwiększenie bezpieczeństwa w pracy są przykładowo:

- zapewnienie dobrej komunikacji pomiędzy pracownikami i kierownictwem, jak

i wprowadzeniem obowiązku informowania przełożonych o zagrożeniach na stanowisku pracy,

- zwiększenie zaangażowania kierownictwa w sprawy pracowników,

- stworzenie systemu ewidencji środków ochrony indywidualnej oraz dostosowanie odzieży i obuwia do zmiennych warunków atmosferycznych i rodzaju wykonywanej pracy,

- wprowadzeniu środków ochronnych na skórę twarzy,

- umożliwienie dokształcania się i uczestnictwa w kursach z branży górniczej.

Działania te mogą zapewnić bezpieczne miejsce pracy w Zakładzie Eksploatacji Kruszywa Czarna Sędziszowska, jak i w innych zakładach odkrywkowych.

\section{Bibliografia}

[1] Pacana A. "Analiza liczby zbadanych wypadków przy pracy", w Światowy Dzień Bezpieczeństwa i Ochrony Zdrowia w Pracy, R. Ulewicz, J. Żywiołek, Częstochowa: Oficyna Wydawnicza Stowarzyszenia Menedżerów Jakości i Produkcji, 2017, s. 5567.

[2] Pacana A., Ingaldi M., Czajkowska A. Zarzadzanie bezpieczeństwem i produkcja $z$ uwzględnieniem Lean Manufacturing. Oficyna Wydawnicza Stowarzyszenia Menedżerów Jakości i Produkcji: Częstochowa, 2016, s. 16-20.

[3] Ejdys J. Ksztattowanie kultury bezpieczeństwa i higieny pracy w organizacji. Oficyna Wydawnicza Politechniki Białostockiej: Białystok, 2010, s. 11-22.

[4] Pacana A. Synteza systemowego zarządzania bezpieczeństwem $i$ higiena pracy. Oficyna Wydawnicza Politechniki Rzeszowskiej: Rzeszów, 2016, s. 109-110.

[5] Ejdys J., Kobylińska U., Lulewicz-Sas A. Zintegrowane systemu zarządzania jakościq środowiskiem $i$ bezpieczeństwem pracy. Oficyna Wydawnicza Politechniki Białostockiej: Białystok, 2012, s. 136-140.

[6] Pacana A. Audity systemów zarządzania bhp. Oficyna Wydawnicza Politechniki Rzeszowskiej: Rzeszów, 2015, s. 7-12.

[7] Pacana A. Projektowanie, wdrażanie i doskonalenie systemów zarządzania bezpieczeństwem i higieną pracy zgodnych z PN-N-18001. Oficyna Wydawnicza Politechniki Rzeszowskiej: Rzeszów, 2015, pp. 34. 
[8] Siwiec D., Pacana A., Olejarz T. "Hazard analysis and accupational risk assessment on the postition roofer with usign the method of Risk Score", in Occupational health and safety at workplaces, A. Pacana, G. Ostasz, Rzeszów: Oficyna Wydawnicza Politechniki Rzeszowskiej, 2018, pp. 81-91.

[9] Wyższy Urząd Górniczy, http://www.wug.gov.pl/ (dostęp: 20.04.2018r.).

[10] Kruszgeo S.A., http://www.kruszgeo.com.pl/ (dostęp: 20.04.2018r.).

[11] 11.Materiały Wewnętrzne Zakładu Eksploatacji Kruszywa Czarna Sędziszowska. Materiały niepublikowane, Czarna Sędziszowska, 2018.

\title{
AN ANALYSIS OF WORK SAFETY IN A PLANT PRODUCING AGGREGATE
}

\begin{abstract}
Together with the growing awareness of employees in the field of occupational safety, the approach to the sphere of safe work is changing. Due to numerous threats occurring in the mining industry, analysis were carried out aimed at proposing the possibility of providing a safe workplace. The analysis was carried out at the ZEK Czarna Sedziszowska mining plant producing, which is one of the plants owned by the Kruszgeo. The statistical data collected from the State Mining Authority regarding the incidents in opencast mining in the years 2010 - 2017 were analyzed. The statistical data collected from the State Mining Authority regarding the incidents in opencast mining in the years 2010 - 2017 were analyzed. Next, the results of the questionnaires subsequently was analyzed, which was carried out among all the employees of the discussed plant. The surveys concerned safety at work and ailments experienced by employees. The selected survey results were compared with the occupational risk assessment results carried out in accordance with PN-N-18002. The conducted analysis and proposed possibilities to increase work safety can provide a safe workplace at ZEK Czarna Sędziszowska and other opencast plants.
\end{abstract}

Key words: safety, OHS, aggregate

Data przestania publikacji do Redakcji: 20.06.2018

Data akceptacji publikacji przez Redakcję: 28.07.2018 